Journal of Social Sciences 6 (3): 386-388, 2010

ISSN 1549-3652

(C) 2010 Science Publications

\title{
Phi Ti Su Khwan: Conservation and Transmission of the Spiritual Encouragement-Ritual of People in Isan Society
}

\author{
Witthaya Phukhronghin, Songkoon Chantachon and Sastra Laoakka \\ The Research Institute Northeastern of Art and Culture, \\ Mahasarakham University, 44001, Thailand
}

\begin{abstract}
Problem statement: Phi Ti Su Khwan is a ritual of Isan people (northeast people of Thailand) which is performed for encouraging power of life of people at an appropriate period in their lifetime. Khwan (spirit) is a non-physical part of body; it acts as consciousness which affects physical health. At present, the majority of ritual leaders are very old and they seem to lack their descendants because the descendants lack knowledge, skill and qualifications concerning spiritual encouragementritual. The purposes of this research were to investigate the difficulties of conservation and transmission of spiritual encouragement-ritual and to conserve and transmit it in Isan society. Approach: Research areas are Kaksin, Maha Sarakham and Khon Kaen Province which locate in the north of northeastern Thailand. These areas have the diversity of traditions, culture and ethnic groups. Moreover, they are old provinces where the ritual leaders have lived and transmitted spiritual encouragement-ritual to new generation until now. The data were collected from 123 ritual leaders by means of a survey, an interview, an observation and a focus group interview. Research results were presented by means of a descriptive analysis Results: (1) The difficulties of conservation and transmission of spiritual encouragement-ritual revealed that the majority of ritual leaders in Isan society were very old and they seemed to lack their descendants because the descendants lacked knowledge, skill and experience concerning spiritual encouragement-ritual so people in Isan society revealed that there were 4 ways of transmission: The first, it was transmitted through temples or communities, the third, it was transmitted through senior-ritual leaders and the fourth, it was transmitted through self-learning. Conclusion/Recommendations: The leader of spiritual encouragement-ritual must has extra characteristic that differs from general person in order to maintain his successful life and people's acknowledgement.
\end{abstract}

Key words: Spiritual encouragement-ritual, conservation, perpetuation, power of life, Isan society

\section{INTRODUCTION}

The beliefs of people in Isan society (northeastern society of Thailand) originate significantly many rituals. Spiritual encouragement-ritual is a ritual which aims at encouraging power of life, communicating and giving the meanings of the phenomena which happen in the lifetime of persons, animals or things. Some examples of spiritual encouragement-rituals for persons are a spiritual encouragement-ritual for a candidate for the Buddhist priesthood, a spiritual encouragementritual for a monk, a spiritual encouragement ritual for a child, a spiritual encouragement-ritual for pregnant women, a spiritual encouragement-ritual for a married couple, a spiritual encouragement-ritual for a congratulatory occasion, a spiritual encouragementritual for freshmen. Some examples of spiritual encouragement-ritual for animals are a spiritual encouragement-ritual for elephants, a spiritual encouragement-ritual for cattle. And some examples of spiritual encouragement-ritual for things are a spiritual encouragement-ritual for a house, a spiritual encouragement-ritual for a cart, a spiritual encouragement-ritual for a car, a spiritual encouragement-ritual for moneybag, a spiritual encouragement-ritual for a gold bag.

Generally, humans believe in the same thing that each person consists of body and mind, good interaction between the body and mind of each person enhances good life. A non-physical part of body which acts as consciousness and it affects physical health; Isan people (northeastern people of Thailand) call it Khwan. If Khwan (spirit) still lives in one's body, physical health and mental health is also good but if it goes

Corresponding Author: Witthaya Phukhronghin. Institute Northeastern of Art and Culture, Mahasarakham University, 44001, Thailand 
away, illness or unhappiness will come instead (Anuman, 1998). Thus a spiritual encouragement-ritual is necessary for reinforcing power of life of each person in ordered to overcome the difficulties in one's life. A spiritual encouragement-ritual for animals aims at consoling and apologizing them for serious scolding, beating and apologizing them for serious scolding, beating or commanding. A spiritual encouragementritual for things or sacred things aims at reinforcing auspicious power, safe power, protective power and useful power. Three elements of a spiritual encouragement-ritual consist of a Mo Sut (the leader of a spiritual encouragement-ritual), spirit offerings and the process of a spiritual encouragement-ritual.

Because of this ritual enhances power of life and encourages physical and mental health of each person so it is classified into a group of psychotherapy rituals in traditional Thai medicine. Empirical truth reveals that only modern medicine cannot absolutely solve both physical and mental health, studying and applying traditional Thai medicine to a cure in all involvements is necessary and should operate parallel to modern medicine, so Phi $\mathrm{Ti} \mathrm{Su}$ Khwan or a spiritual encouragement-ritual is a cultural system which plays a role as a way to maintain the balance between physical and mental health and it is consistent with natural and socio-cultural context of each local area. Thus conservation and transmission of spiritual encouragement-ritual needs a serious study in order to develop and apply it to a sustainable operation which encourages community participation and interactive learning in community (Keranpong, 1982). Purposes and objectives: The purposes of this research were to investigate the difficulties of conservation and transmission of spiritual encouragement-ritual and to conserve and transmit it in Isan society.

\section{MATERIALS AND METHORDS}

Pupation and sample: A sample of 123 ritual leaders was collected from Kalasin, Maha Sarakham and Khon Kaen Province. These areas locate on the north of northeastern Thailand and have the diversity of traditions, culture and ethnic groups. Moreover, they are old provinces where the ritual leaders have lived and transmitted spiritual encouragement-ritual to new generation until now.

Instruments: Research instruments used for collecting data were a survey, an interview and observation and a focus group interview.

Data analysis: Research results were presented by means of a descriptive analysis.

\section{RESULTS}

Research results revealed the following:

- The difficulties of conservation and transmission of spiritual encouragement-ritual were the majority of ritual leaders in Isan society were very old and they seemed to lack their descendants because the descendants lacked knowledge, skill and experience concerning a spiritual encouragementritual so people did not believe in them

- The conservation and transmission of the spiritual encouragement-ritual of people in Isan society was transmitted by 4 ways: The first, it was transmitted through family and relatives; the second, it was transmitted through temples and communities; the third, it was transmitted through senior-ritual leaders and the fourth, it was transmitted through self-learning

\section{DISCUSSION}

At present the main difficulty in conservation and transmission of spiritual encouragement-ritual is lack of descendants who transmit it to future generation because new generation are educated under modern curriculum which focuses on scientific thinking so they do not understand indigenous knowledge. The researchers found that lacking of academics who appreciated traditional Thai medicine, Jacking of organizations conserving this ritual and lacking of economic benefit led to lacking of public mind. In the past, a person wanted to be a leader of spiritual encouragement-ritual in order to help other people with public mind but nowadays this ideal is changed because economic needs rather influence the ways of life of people. This is congruent with the article of Khunphakdi (1997) which writes that "all ritual leaders wanted to hand down this ritual to descendants who had appropriate qualifications but each ritual leader had his specific regulations which used for screening the descendant for a reason of he could persuade people to believe in him and to practice faithfully this ritual".

The conservation and transmission of the spiritual encouragement-ritual of people in Isan society was transmitted by 4 ways: The first, it was transmitted through family and relatives; the second, it was transmitted through temples and communities; the third, it was transmitted through senior-ritual leaders and the fourth, it was transmitted through self-learning. This is congruent with the research of Pornsiripong et al. (1996) entitled "A Study of The Thai Indigenous Knowledge: Pho Yai Chan Khen Lawong" which 
reveals that "illness is a natural phenomenon which happens to everybody in every society and nobody can avoid it so everybody must find the ways to overcome it, each way is different according to an economic factor, a social factor, an environmental factor, including the combination of external and internal culture. Traditional Thai medicine is a cure for illness which originates from ancestral experience and is adapted to socio-cultural context of each ethnic group. It is a medicinal system which has played a role in community health service for a long time because it is a simple treatment which gets along with the ways of life of community".

\section{CONCLUSION}

The leaders of spiritual encouragement-ritual must have more particular characteristics than general people in order to lead their successful life and can cure sick people feel better. Moreover, their particular characteristic influence people to believe in their curing efficiency which is one reason for making people's acknowledgement. The leaders of spiritual encouragement-ritual must believe in Buddhist doctrines and integrate them into the faith in practicing spiritual encouragement-ritual which is a ritual for enhancing mental health and healthy security of sick people.

\section{ACKNOWLEDGEMENT}

This research was supported by the Research Institute of Northeastern Art and Culture, Mahasarakham University. The authors wish to express their sincere thanks to the research institute of Northeastern Art and Culture and the leaders of spiritual encouragement-ritual in the provinces of Kalasin, Mahasarakham and Khon Kaen. They would like to express their sincere appreciation for all of the support provided.

\section{REFERENCES}

Anuman, P., 1998. The Ancient Thai Life. 2nd Edn., Rayal Institute, Bangkok, ISBN: 9748122115, pp: 174.

Keranpong, C., 1982. A history of medicine in rettanakosin period. Mahidol University. http://library.bu.ac.th/oldversion/onlineservice/Res ultTitle.cfm?aTextSearch=2001050050\&aSearchB $\mathrm{y}=\mathrm{B} \&$ aIs Advance $=$ No

Khunphakdi, N., 1997. An Analysis of the Beliefs of Thai Men in Swasdi Raksa. 1st Edn., Silpakorn University, Nakhon Pathom, ISBN: 9746002708, pp: 246.

Pornsiripong, S., P. Usuparat and P. Sapcharoen, 1996. A Study of the Thai Indigenous Knowledge: Pho Yai Chan Khen Lawong. 2nd Edn., The Traditional Thai Medicine Institute, Bangkok, ISBN: 9745884251, pp: 176. 